\title{
Role of Intestinal Microbiota in Inflammatory Bowel Diseases
}

\author{
Chang Soo Eun \\ Department of Internal Medicine, Hanyang University Guri Hospital, Hanyang University College of Medicine, Guri, Korea
}

A vast number of micro-organisms within the human gut play a crucial role in maintaining human health. Intestinal microbiota maintains the intestinal homeostasis and function by mutually interacting with the host's epithelial cells and mucosal immune system; and the immune tolerance towards intestinal commensals should be permitted for such interactions to occur. In recent years, the prevalence of inflammatory bowel diseases has greatly increased, and the pathogenic pathway behind is considered to be related to an aggressive immune response which is a subset of commensal enteric bacteria in a genetically susceptible host. The abnormal host-microbial interactions play an important role in the pathophysiology of inflammatory bowel diseases, which have been proved through numerous studies in the field of genetics, molecular microbiology, immunology, and experimental rodent models, as well as various translational researches and clinical trials. This review briefly summarizes the composition and function of intestinal microbiota, interactions between the microbiota and the immune system, and the possible roles of the intestinal microbiota in the pathogenesis of inflammatory bowel diseases. (Intest Res 2013;11:161-168)

Key Words: Microbiota; Inflammatory bowel diseases; Host-pathogen interaction

\section{서 론}

인체의 위장관에는 수많은 미생물들이 군집을 이루고 있으며, 장내 세균총(intestinal microbiota)은 장의 항상성과 기능을 유지하는 데 필수적이고, 이를 위해선 장내상재균(commensal)에 대한 면역관용 (tolerance)이 유지되어야 한다. 반면에 특정 병원균이 군집을 이루면 인체에 해가 되고 감염질환을 유발할 수 있다. 따라서 인체는 해가 없 는 세균의 감염이나 군집 형성에는 항상성 반응을 하고 병원균에 대 해선 방어기전을 작동하게 된다.

염증성 장질환은 유전적인 소인을 가진 사람의 위장관에서 발생하 는, 정확한 원인을 알 수 없는 복잡한 만성 염증 질환으로 최근 발생 빈도가 급격하게 증가하고 있다. 과거에는 특정 병원균이 크론병이나 궤양성 대장염을 유발한다고 추측하였으나, 지금은 장내 상재균이 지 속적인 항원자극을 유발함으로써 병원성 $\mathrm{T}$ 세포를 꾸준히 활성화시 켜 만성 장손상을 일으킨다고 생각하고 있다. ${ }^{1,2}$

Received July 2, 2013. Revised July 3, 2013. Accepted July 4, 2013 Correspondence to Chang Soo Eun, Department of Internal Medicine, Hanyang University Guri Hospital, 153 Gyeongchun-ro, Guri 471-701, Korea. Tel: +82-31-560-2228, Fax: +82-31-555-2998, E-mail: cseun@ hanyang.ac.kr *This study was supported by a grant of the Korean Health Technology REtD Project, Ministry of Health \& Welfare, Republic of Korea (A120176).
그동안 유전학, 분자미생물학, 면역학, 실험동물모델, 면역진단학 분야의 많은 연구들과 중개연구(translational research) 및 임상시험 을 통해 염증성 장질환의 병태생리에서 비정상적인 인체-미생물 상 호작용(host-microbial interaction)이 중요한 역할을 함을 알게 되었 다. 이 종설에서는 정상 장내세균의 조성과 기능, 장내세균과 면역계 의 상호작용, 그리고 염증성 장질환의 병태생리에서 장내세균의 역할 에 관하여 간략히 정리해 본다.

\section{장내세균의 정착}

사람이 영유아기에서부터 노년층까지 발전하고 변화하듯이, 장 내세균총도 시간이 지남에 따라 변화한다. 일반적으로 출생 전 산모 의 자궁 내에서 태아의 장은 무균 상태이다가, 출생 시에 분만방법에 따라 산모의 질이나 피부에 존재하는 세균들이 빠른 속도로 정착한 다. ${ }^{3.4}$ 그 후 시간이 지남에 따라 장내세균의 다양성이 점차 증가하며, 부모와의 지속적인 접촉, 식사 종류(모유 수유, 고형식), 항생제 사 용 등 유아기의 여러 환경인자들에 따라 장내세균 조성에 많은 변화 가 나타난다. ${ }^{5}$ 질식분만과 모유 수유를 하면 유아기에 Lactobacillus 와 Bifidobacteria의 군집이 증가한다. ${ }^{6}$ 장내세균 조성은 생후 1 년이 되면 점차 성인의 조성과 유사해지며, 2.5 세가 되면 장내세균 조성이

\footnotetext{
๑ Copyright 2013. Korean Association for the Study of Intestinal Diseases. All rights reserved.

This is an Open Access article distributed under the terms of the Creative Commons Attribution Non-Commercial License (http://creativecommons.org/licenses/by-nc/3.0)

which permits unrestricted non-commercial use, distribution, and reproduction in any medium, provided the original work is properly cited.
} 
성인과 거의 흡사해지고 그 후에는 노년층에 이를 때까지 대부분 안 정적으로 유지된다. ${ }^{7.8}$ 노년층의 장내세균 조성은 젊은 성인과 달라서, Bacteroides species와 Clostridium 그룹의 조성 변화가 심한데 이는 나이가 듦에 따라 다양한 질환의 유병률이 증가하고 여러 약제에 노 출되기 때문일 수 있다. ${ }^{9}$ 유아기의 장내세균총은 불안정하고 다양하 여 여러 환경인자들에 의해 장내세균 조성이 급격하게 바뀔 수 있는 데, 장내세균총의 확립에 중요한 이 시기의 장내세균 조성은 향후 성 인에서의 건강 및 염증성 장질환, 당뇨병, 천식 등과 같은 여러 질환 발생에 밀접한 관련이 있다고 보고된다. ${ }^{1011}$ 최근 여러 역학 연구들에 서는 영유아기의 항생제 사용이 성인에서의 염증성 장질환 발생 위험 을 증가시켰다. ${ }^{12}$

\section{장내세균의 조성, 기능 및 항상성 기전}

위장관내 복잡한 미생물 생태계는 장내세균 중 어떤 특정 성분이 장염유발에 관여하는지 알기 어렵게 한다. 따라서 장염의 병태생리에 서 장내세균의 역할을 규명하고자 한다면, 정상인과 환자에서 장내 미생물체(microbiome)의 특징을 종합적으로 밝히는 것이 중요하다. 대부분의 장내세균이 통상적인 배양 방법으로는 발견이 안되므로 그 동안 복잡한 장내세균 생태계의 연구는 많은 어려움이 있었으나, 최 근 $16 \mathrm{~S}$ ribosomal DNA와 RNA의 염기서열을 이용한 분자생태학적 인 분석법이 도입됨에 따라 인체와 동물모델의 장내세균 조성에 대하 여 보다 자세히 분석할 수 있게 되었다. ${ }^{13}$

과거 배양방법으로는 대장내 균종(species)을 200-300개 정도 측정할 수 있는 것에 불과했으나, 분자생태학적인 방법에 의해서는 1,800 개의 속(genus)과 $15,000-36,000$ 개의 종이 측정된다. ${ }^{14}$ 장관 내 전체 미생물 수는 $10^{13}-10^{14}$ 개로 인체 게놈보다 적어도 100 배 많 다. ${ }^{15}$ 세균을 포함한 미생물들은 위장관 근위부에서 원위부로 갈수 록 농도와 복잡성이 증가하는데, 위와 십이지장 내에는 $10^{2}-10^{3}$ 개/ $\mathrm{g}$ 의 호기성 세균이 존재하는 반면에 맹장과 대장에는 $10^{11}-10^{12}$ 개/g 의 혐기성 세균이 존재한다. 장내세균의 $99 \%$ 이상은 네 종류의 문 (phylum)에 속하는데, 여기에는 Firmicutes, Bacteroidetes, Proteobacteria, 그리고 Actinobacteria가 있다. ${ }^{4}$ 장내세균은 개개인 뿐만 아 니라 해부학적인 위치, 식이와 건강 상태에 따라 다양한 조성을 보인 다. ${ }^{16}$

다양한 장내세균은 비흡수성 탄수화물, 탈락된 상피세포, 점액을 능동적으로 대사시켜 많은 대사산물을 만들어내므로 장상피기능, 인 체 에너지 균형, 면역반응에 중요한 영향을 미친다. ${ }^{15}$ 장내세균, 특히 Clostridium 과 같은 Firmicutes나 Bifidobacterium은 식이섬유를 단 쇄지방산으로 대사시키는데, 이는 인체 에너지원의 $10 \%$ 를 차지한다. 장내세균은 담즙산을 대사시키고, 역으로 담즙산은 장내세균 작용과 유전자 발현에 영향을 미친다. ${ }^{17}$

장내세균은 인체 내에서 영양분의 흡수와 교환, 장상피장벽의 형 성과 강화, 장 면역계의 발달 및 병원균에 대한 방어와 같은 여러 생 리적인 과정에 중요한 역할을 한다. ${ }^{18}$

건강한 인체에서 장내세균은 상피세포, 대식세포, 수지상세포 (dendritic cell), $\mathrm{T}$ 림프구, $\mathrm{B}$ 세포에 의한 항상성 반응을 활성화시켜
장내에서 잠재적인 병원성 세균 산물과 공존할 수 있게 한다..$^{19}$ 이러 한 항상성 기전에는 세균 수용체의 하향조절, 선천면역과 후천면역반 응을 억제하는 물질 유도, 그리고 장점막 장벽기능을 매개하는 보호 물질의 활성화 등이 있다. 세포외 toll-like receptor (TLR)와 세포내 NOD-like receptor (NLR)를 포함한 형태인지수용체(pattern recognition receptor)가 세균을 인지하고, ${ }^{20}$ 세균 수용체의 결합은 nuclear transcription factor kappaB $(\mathrm{NF}-\kappa \mathrm{B}), \mathrm{AKT} / \mathrm{PI} 3 \mathrm{~K}, \mathrm{MAPK}$ 경로와 같은 중앙 신호단계를 활성화시키는데, 이러한 경로를 억제하기 위해 서 장내 상재균은 $\mathrm{A} 20, \mathrm{PPAR} \gamma, \mathrm{NF}-\kappa \mathrm{B}$ 억제제, $\mathrm{IFN} \alpha / \beta, \mathrm{IL}-10$, $\mathrm{TGF}-\beta, \mathrm{PGE} 2$ 등과 같은 억제 물질을 유도한다. 이러한 억제경로의 적절한 조절을 위해서는 상피세포와 점막고유층(lamina propria)의 조절 림프구간 상호작용이 필요하다. 요약해 보면, 정상적인 상태에 서 장내세균의 역할은 병원성의 선천면역(innate immunity) 및 적응 면역(adaptive immunity) 반응을 억제하고, 항균펩타이드 분비를 유 도하며, 상피 재생을 촉진하여 궁극적으로는 장점막 항상성을 유지하 는 것이다. ${ }^{21}$

\section{숙주 면역계의 장내세균에 대한 영향}

숙주 면역계는 숙주 조직과 장내세균간의 상호작용뿐만 아니라 장 내세균의 조성을 조절함으로써 장내세균과의 항상성을 유지한다. 장 면역계의 중요한 기능 중의 하나는 숙주 조직에 대한 장내세균 노출 을 최소화함으로써 병원성 면역반응의 가능성을 줄이는 것이다.

장내세균과 장상피세포의 직접적인 접촉을 최소화하기 위해서 장 내 goblet 세포는 뮤신 당단백을 분비하여 점액층을 형성함으로써 장 내세균의 장상피내 침입을 억제하고, ${ }^{22}$ 소장상피에서 TLR 경로를 통 해 분비하는 항균펩타이드인 RegIII $\gamma$ 역시 소장상피층과 장내세균의 접촉을 억제한다. ${ }^{23}$ 장점막의 수지상세포는 장관내 일부 세균을 인지 한 후 Peyer's patch내 B세포와의 상호작용을 통해 특정세균에 대한 $\operatorname{IgA}$ 를 분비하게 함으로써 분비형 $\operatorname{IgA}$ 가 장내세균과 결합하여 장상 피장벽의 통과를 예방한다. ${ }^{24}$

장상피장벽을 통과한 세균을 장점막층에 국한시키고, 전신면역계 에 노출되지 않도록 하기 위해서 점막고유층의 수지상세포가 장벽을 통과한 세균을 삼켜서 장간막림프절로 이동함으로써 전신 2 차 림프 절로의 침입을 억제한다. 장간막림프절에서 만들어진 분비형 $\operatorname{IgA}$ 는 활성화된 $\mathrm{B}$ 세포와 $\mathrm{T}$ 세포에 의해 전 장 점막 표면에 분포하여 특정 세균에 대한 방어작용을 한다. ${ }^{25}$ 점막고유층의 선천림프세포(innate lymphoid cell)는 IL-22를 분비하여 세균을 장점막에 국한시키고 전 신면역계로 퍼지는 것을 예방하는 역할을 한다. ${ }^{26}$

또한 숙주 면역계는 장내세균 조성의 조절에 중요한 역할을 하는 데, 이는 특정 면역결핍 동물 연구를 통해 증명되었다. 염증반응을 조 절하는 전사인자인 T-bet 결핍은 적응면역이 없는 Rag2결핍 마우스 에서 장내세균 조성을 변화시키고 장염을 자연 발생시켰으며, 특징 적으로 장염 마우스의 대변을 유전적인 소인이 없는 야생형 마우스에 접종하였을 때 장염이 발생하였다. ${ }^{27}$ 세균 편모를 인지하는 수용체인 TLR5결핍 마우스에서는 장내세균 조성 변화와 함께 인슐린 저항성 을 특징으로 하는 대사증후군이 발생하였고, 대변을 정상 마우스에 
접종하였을 때 유사한 대사증후군이 전달되었다. ${ }^{28}$ 요약해 보면, 숙주 면역계는 장내세균의 조성, 다양성, 위치 등을 적절하게 조절하고 있 는데, 만약 숙주 면역계에 이상이 생기면 장내세균총 역시 혼란이 발 생함을 알 수 있다.

\section{장내세균의 숙주 면역계에 대한 영향}

무균상태(germ-free, GF)의 마우스와 장내세균이 존재하는 specific pathogen free $(\mathrm{SPF})$ 마우스를 비교해 보면 림프조직의 형성과 면역계 발달에 대한 장내세균의 중요한 영향을 알 수 있다. GF 마우 스는 SPF 마우스에 비해 Peyer's patches수, 점막고유층 두께, germinal center 내 형질세포(plasma cell)수, 그리고 림프여포(lymphoid follicle)수가 적으며, IgA를 만드는 $\mathrm{B}$ 세포 뿐만 아니라 $\mathrm{T}$ 세포와 $\mathrm{Pa}-$ neth 세포수 역시 적다. ${ }^{29}$

장내세균은 출생 후 초기부터 장 연관 림프조직의 성숙에 관여하 는 신호를 만들어 숙주의 장 면역계 발달에 영향을 미친다. 그람 음성 peptidoglycan 은 장내 고립형 림프여포가 성숙하는데 필요하며, ${ }^{30}$ 장 내세균은 $\operatorname{IgA}$ 를 분비하는 형질세포와 T세포를 장점막층으로 끌어들 이고, 수지상세포와 장상피세포의 crosstalk를 용이하게 함으로써 장 내 B세포와 T세포 반응의 강도를 조절한다. ${ }^{31}$ 수지상세포는 숙주 면 역계에 대한 장내세균의 영향을 매개하는 중요한 역할을 하는데, 수 지상세포는 TLR과 같은 패턴인지수용체를 통해 장내세균을 인지하 고 반응함으로써 뒤이은 $\mathrm{T}$ 세포 반응의 양상을 조절한다. ${ }^{32}$ 또한 이 러한 장내 수지상세포 작용은 장내세균의 조성에 따라 영향을 받는 다. ${ }^{33}$

여러 연구를 통해 점막고유층의 개개의 특정 $\mathrm{T}$ 림프구가 특징적인 작용을 하는 데 있어서 장내세균이 중요한 역할을 함을 알게 되었다. Segmented filamentous bacteria (SFB)는 장 점막고유층의 Th17세 포 증식을 유도하고 항균펩타이드 분비를 촉진함으로써 병원균에 의 한 장염 발생을 억제하였다. ${ }^{34} \mathrm{GF}$ 마우스에 Clostridial strain 46종 (cluster IV와 XIVa)을 혼합하여 접종하였을 때 점막고유층과 전신 에 IL-10을 표현하는 유도형 조절 T세포(inducible regulatory T cell, iTregs)가 증가하였다. ${ }^{35}$ Bacteroides fragilis 에서 나오는 polysaccharide A라는 물질은 장내 T세포의 IL-10 분비를 증가시킴으로써 $\mathrm{Th} 17$ 세포의 팽창을 억제하고 장점막 방어벽 손상을 예방하였다. ${ }^{36}$ 이 와 같은 결과를 종합해 보면 장내세균이 장점막 면역기능의 항상성 을 유지하는 데 중요한 역할을 함을 알 수 있다.

\section{염증성 장질환 위험 유전자와 장내세균}

$N O D 2, A T G 16 L 1, I R G M$, 그리고 OCTN1/2와 같은 선천면역과 관련이 있는 여러 유전자들의 돌연변이를 통해 침습성 세균에 대한 선천면역반응과 크론병 발생과의 연관관계를 알게 되었다. ${ }^{37}$ 장내세 균을 조절하는 중요한 면역매개 인자들로는 Paneth 세포, MyD88, TLR, unfolded protein response (UPR), autophagy, 그리고 NOD2 등이 있고, 이러한 다양한 면역매개 경로들에 손상을 유발하는 요소 들은 장내세균의 조절 장애를 초래한다. ${ }^{38}$
Paneth 세포는 주로 회장말단부의 장샘 기저부에 존재하는 상피 세포 중의 하나로, 직접적으로 장내세균을 인지하고 TLR의 MyD88 의존 경로를 통해 항균펩타이드 합성을 조절함으로써 숙주 조직으로 의 세균 침입을 억제한다. ${ }^{39}$ Paneth 세포의 기능과 항균작용은 UPR, autophagy, 그리고 NOD2와 같은 많은 면역경로와 유전자들에 의해 조절된다. ${ }^{40}$

세균의 세포벽 성분인 muramyl dipeptide를 인지하는 NOD2의 돌 연변이는 IL-10 발현을 감소시키고 염증반응 을 증가시킨다. ${ }^{41} N O D 2$ 는 Paneth 세포 표면에 발현되는 단백질을 조절하기 때문에 NOD2 돌연변이는 장내세균의 조성과 함께 면역계와 장내세균의 균형 유지 에 영향을 미친다. ${ }^{42}$ 최근 서양 연구에서는 NOD2와 ATG16L1 유전 자 돌연변이를 가진 크론병 환자들에서 장내세균 조성의 변화, 특히 Faecalibacterium과 Escherichia속의 의미있는 변화가 관찰되었다. ${ }^{43}$ 또한 동물실험에서도 야생형 마우스에 비해 NOD2 결핍 마우스에서 는 장내세균량이 증가하였고, 새롭게 정착한 세균을 제거하는 능력 이 감소되었다. ${ }^{44}$ 또한, $\mathrm{NOD} 2$ 가 이유기 마우스에서 장내세균총을 형 성해 나가는 데 중요한 역할을 함이 입증되었다. ${ }^{45}$

Autophagy는 endoplasmic reticulum (ER) 스트레스와 같은 각종 세포 자극에 의해 나타나는 자가소화과정으로, 이에 관련된 대표적인 유전자로 $A T G 16 L 1$ 과 $I R G M$ 이 있다. ${ }^{40} A T G 16 L 1$ 유전자 돌연변이는 숙주의 세포내 병원균 제거에 장애를 초래하며, ATG16L1 발현 정도 가 감소하면 Paneth 세포의 장애가 나타나 항균펩타이드 합성 이상으 로 장내세균총에 영향을 미친다. ${ }^{46}$

그러나, 염증성 장질환 연관 유전자 변이가 질환의 기전을 이해하 는 데 중요한 요소이지만 이들만으로 질환 전체를 이해할 수는 없고 많은 환경인자들이 관여한다. 쌍둥이 연구를 살펴보면 일란성 쌍생아 의 질환 일치율이 크론병은 $35 \%$, 궤양성 대장염은 $16 \%$ 여서 유전인 자와 환경인자간의 상호작용이 중요하고, 유전인자보다는 장내세균 노출과 같은 환경인자의 영향이 보다 큰 역할을 함을 시사하였다. ${ }^{47}$

\section{염증성 장질환에서 장내세균 조성의 변화}

최근 $16 \mathrm{~S}$ ribosomal DNA와 RNA (16S rRNA)의 염기서열을 이 용한 분자생태학적인 분석법이 도입되면서 정상인과 염증성 장질환 환자의 대변과 장점막조직의 장내세균 조성에 대하여 많은 연구가 발표되었다. 대부분의 연구에서 정상인에 비해 활동성 염증성 장질 환 환자의 대변과 점막조직 내에는 장내세균 다양성이 현저히 감소 하고, 장내 상재균의 상당부분을 차지하는 Firmicutes는 감소하며, Escherichia coli를 포함한 Enterobacteriaceae는 증가하였다. ${ }^{14,48,49}$ 염 증성 장질환에서 Firmicutes의 감소는 상당부분 Clostridium XIVa와 IV 그룹의 감소 때문이고, Firmicutes는 장내에서 강력한 항염증작용 을 가진 acetate, butyrate와 같은 중요한 단쇄지방산을 합성하는 역 할을 하기 때문에 ${ }^{50,51}$ 염증성 장질환 환자에서 Firmicutes의 감소로 인한 항염증 대사산물과 염증조절 리간드 등의 결핍이 중요한 역할을 함을 추측해 볼 수 있다. 일부 연구에서는 크론병 환자에서 Clostridium leptum 그룹 중 대표적인 항염증작용을 하는 Faecalibacterium prausnitzii 의 감소를 보고하였는데, ${ }^{14,52}$ 이러한 균주의 결핍이 인체의 
장내세균총에 대한 관용의 혼란을 초래하여 장염 발생과 관련이 있 을 것으로 생각하고 있다.

그러나 아직까지 크론병과 궤양성 대장염 간의 장내세균 조성 차이 에 대해선 논란이 있다. 일부 연구에서는 두 군 간에 장내세균 조성이 비슷하였으나, ${ }^{53}$ 다른 연구에서는 두 군 간 뚜렷한 장내세균 조성의 차이가 있었다. ${ }^{54}$ 최근 메타지노믹 시퀀스 분석을 시행한 연구들에서 는 두 군 간 대변과 점막조직내 장내세균 조성의 분명한 차이를 보고 하였다. ${ }^{13,43}$ 이러한 상이한 연구결과는 아마도 장내세균 조성의 분석 방법, 대상 환자군의 특성(질환 활성도, 유병기간 및 치료), 그리고 대 상샘플 위치의 차이 등에 기인하며, 따라서 연구 간 비교에서는 이러 한 변수들의 표준화가 필요하다.

염증성 장질환 환자에서 염증부위와 염증이 없는 부위 간에 장내세 균 조성의 차이를 분석한 연구들을 살펴보면, 일부에서는 두 군 간에 차이가 없다고 보고하였으나, ${ }^{5}$ 최근 high throughput clone library 분 석을 시행한 연구에서는 염증부위와 비염증부위 사이에 분명한 장내 세균 조성 차이를 보였다. ${ }^{56}$ 그러나 각 그룹 내 개인별 차이가 심했고, 염증부위와 연관된 특정 세균층을 분석하지는 못해서 앞으로 많은 연 구가 필요하다.

한편, 정상인에서 대변 내 장내세균과 점막조직 내 장내세균의 조 성 차이에 대한 여러 연구가 시행되었는데, 상당수의 연구에서 대변과 점막조직 간 장내세균 조성의 분명한 차이를 보고했다. 57,58 이들 연구 에서는 대변 내 장내세균 조성이 점막조직 내 조성을 반영하지 못한 다고 보고했으며, 염증성 장질환, 특히 크론병의 장내세균 조성 분석 및 정상인과의 비교연구에서는 점막조직 분석이 보다 중요함을 시사 하였다.

현재까지의 대부분의 장내세균 연구들은 특정시점에서의 결과만 을 분석하였고, 주로는 서양인들을 대상으로 진행되어 왔다. 그러나 장내세균 조성이 개인간 차이가 심하고 시간에 따라 변할 수 있으며 식이에 큰 영향을 받음을 고려할 때, 동일한 대상에서 시간에 따른 장 내세균 조성의 차이, 그리고 동양인과 서양인 간의 장내세균 조성 차 이를 비교하는 것은 매우 중요하다. 일본인의 장내세균에는 서양인과 다르게 해조류를 소화시키는 데 도움이 되는 해양세균에 존재하는 독특한 효소들이 존재하고 ${ }^{59}$ 아프리카와 유럽의 어린이들을 비교한 연구에서 아프리카 어린이들은 섬유질이 풍부한 식사에서 에너지 흡 수를 최대화하기 위해 Bacteroidetes는 풍부하고 Firmicutes는 결핍 되어 있음이 밝혀진 바 있다. ${ }^{60}$

그 동안 대부분의 장내세균 연구는 주로 정상 또는 질환과 연관된 장내세균 조성에 초점을 맞추어 진행되어 왔다. 최근에는 장내세균 의 기능적인 측면의 분석이 점차 각광을 받고 있는데, 이에는 DNA 수 준에서 장내세균 작용을 분석하는 metagenomics, RNA 수준에서 분 석하는 metatranscriptomics, 단백질 발현 정도로 장내세균 작용을 분석하는 metaproteomics, 그리고 장내세균의 대사산물을 분석하는 metabolomics 가 포함된다. ${ }^{15,61-63}$

\section{염증성 장질환에서 특정 장내세균 연구}

염증성 장질환에서 장내세균의 역할을 규명하기 위한 접근방법으
로 전반적인 장내세균 조성의 불균형(dysbiosis)에 대한 연구 외에 병 원성을 가진다고 생각되는 특정세균의 역할에 대한 연구들이 진행되 어 왔다. 주로는 E. coli와 Mycobacterium avium subspecies paratuberculosis (MAP)라는 두 종의 특정세균들에 대한 연구가 발표되었 다.

크론병과 궤양성 대장염 환자의 점막층에는 정상 대조군에 비해 E. coli의 수가 의미있게 증가하였고, ${ }^{64}$ 크론병 환자의 회장점막과 수 술 후 신생 말단회장부에서 부착침입형 E. coli (adherent-invasive E. coli, AIEC)가 높은 빈도로 발견되었다. ${ }^{65} \mathrm{AIEC}$ 는 type 1 pili, flagella, 그리고 outer membrane porin $\mathrm{C}$ 와 같은 독성인자들을 통해 장 상피세포에 부착하고 침입하며, 식균작용에 저항성을 보이고, 대식세 포의 커다란 공포 내에서 생존하면서 광범위하게 증식할 수 있었다. ${ }^{66}$ AIEC의 type 1 pili는 회장상피세포 표면의 수용체인 CEACAM-6 와 결합함으로써 $\mathrm{AIEC}$ 가 회장상피 표면에 부착할 수 있도록 하는데, CEACAM-6는 정상인에선 발현되지 않는 반면 크론병 환자에서는 $\mathrm{AIEC}$ 를 인지한 대식세포에서 분비한 TNF- $\alpha$ 자극에 의해 회장상피 세포 표면에 과발현되어 AIEC와 결합한다. ${ }^{67}$

$\mathrm{MAP}$ 는 오랜기간 동안 크론병의 가능한 원인으로 생각되었는데, 이는 MAP가 가축에서 유발하는 질환이 인간의 크론병과 유사하고 일부 크론병 환자의 혈청과 장점막에서 MAP가 검출되었기 때문이 다. ${ }^{68}$ 두 개의 메타분석에서는 정상인이나 궤양성 대장염 환자에 비해 크론병 환자에서 MAP DNA나 MAP에 대한 항체가 높은 빈도로 검 출되었으나 69.70 메타분석에 대한 문제점이 제기되었고, 최근의 대규 모 16S rRNA gene library 연구에서는 MAP가 크론병 환자들에서 검 출되지 않았다. ${ }^{1}$ 한편, 염증성 장질환 치료약제인 5-aminosalicylate, methotrexate, 6-mercaptopurine은 MAP 성장을 억제하는데, 치료를 받지 않은 크론병 환자들을 대상으로 한 연구에서는 정상인에 비해 점막조직과 혈청단핵구에서 MAP가 높은 빈도로 검출되었다. ${ }^{71}$

그밖에 Pseudomonas, Yersinia, Listeria, Burkholderia, 그리고 Helicobacter 등이 염증성 장질환과 관련이 있다고 보고되었으나 이들 의 병태생리적 역할에 대하여 연구가 필요하며, 바이러스와 진균의 역 할에 관한 많은 연구도 필요하다. ${ }^{72,73}$

\section{장내세균 항원에 대한 병원성 면역반응 기전}

장내세균 항원에 대한 병원성 면역반응을 유발하는 기전으로 크게 네 가지 가설이 제시되는데, 이들 기전에 의해 점막 $\mathrm{T}$ 세포에 대한 세 균 항원의 노출이 증가하고 장내세균에 대한 숙주 면역반응의 변화 가 초래된다. ${ }^{21}$

첫 번째 기전은 병원성 세균이 장염을 유발한다는 것이다. MAP와 같은 병원균이 염증성 장질환의 원인균일 수 있다고 하였으나 ${ }^{69,70}$ 현 재는 크론병 환자의 궤양 점막에 선택적으로 정착할 뿐이라고 생각 한다. 그러나 ATG16L1, NOD2 또는 NCF4 돌연변이로 세포내 세균 제거 장애를 동반한 일부 크론병 환자에서는 MAP 기회감염이 나타 날 가능성이 있다. AIEC와 같이 장상피세포 부착이나 침입의 기능적 인 변화를 가진 장내상재균은 항균펩타이드 기능 장애의 소인을 가 진 크론병 환자에서 장염을 유발할 수 있다. ${ }^{65}$ 한편, 장독소를 분비하 
는 장내세균인 Clostridium difficile, Enterococcus faecalis, 장독성 Bacteroides fragilis는 인체와 동물모델에서 관해기의 장염을 활성화 시키거나 장염을 유발할 수 있다. ${ }^{74}, 75$

두 번째 기전은 장내세균의 비정상적인 조성변화가 장내 대사산물 의 변화를 초래하여 장점막 투과성을 증가시키고 병원성 면역반응을 유발한다는 가설이다. 염증성 장질환 환자에서는 방어기능을 담당하 는 장내세균의 수는 감소하는 반면, 장염을 악화시키는 균의 수는 증 가한다. ${ }^{14,48}$ Clostridia나 Bacteroides는 대장상피세포의 중요한 에너 지원인 butyrate와 같은 단쇄지방산을 합성하는데, 염증성 장질환에 서는 Clostridium IV와 XIVa 그룹의 농도가 감소하여 대변내 단쇄지 방산 농도가 감소하였다. ${ }^{76}$ 또한 황산염 환원 세균은 황화수소(hydrogen sulfide)의 합성을 증가시켜 대장상피세포에 의한 butyrate 활 용을 억제하고 장점막 투과성을 증가시키는데, 황산염 환원 세균인 Desulfovibrio piger는 염증성 장질환 환자에서 빈도가 증가하였다. ${ }^{77}$

세 번째 기전은 장점막 방어기능, 세포내 세균 제거 및 항균펩타이 드 분비의 장애로 장내세균을 숙주가 제대로 억제하지 못하고 세균 항원 노출이 증가하여 병원성 면역반응이 초래된다는 가설이다. 점 막 투과성 증가는 염증성 장질환의 특징이지만 이러한 변화가 일차 적인 원인인지 이차 현상인지는 논란이 있다. 무증상의 직계가족에 서 자발적으로 또는 비스테로이드 소염제 노출 후 투과성 결함이 발 생한 것은 이것이 일차적인 유전적 결함임을 시사하고, ${ }^{78}$ 장점막 투과 성과 관련된 유전자인 $O C T N 1 / 2$ 와 $m d r-1$ 돌연변이와 염증성 장질 환과의 상관관계가 보고되었다. ${ }^{79,80}$ 크론병 환자에서는 $\alpha$ defensin 5 와 human $\beta$ defensin 2 와 같은 항균펩타이드 합성에 결함이 있 고, ${ }^{81} \mathrm{NOD} 2$ 유전자 돌연변이는 Paneth 세포에 의한 항균펩타이드 합 성 장애와 관련이 있으며, ${ }^{42}$ 세포내 세균 제거를 조절하는 유전자인 ATG16L1과 NCF4의 돌연변이가 크론병과 관련이 있다는 것은 크론 병에서 선천면역반응 결함이 있다는 것을 의미한다. ${ }^{82}$

네 번째 기전은 숙주의 면역조절기능에 장애가 초래되어 세균 항 원 노출이 증가하고 병원성 면역반응이 증가한다는 것으로, 장상피세 포나 점막고유층의 선천 또는 적응면역 세포들 간의 세밀하게 조정된 항상성 기전 중 어느 하나라도 결함이 발생하면 만성 장염을 유발할 수 있다. 상피세포 $\mathrm{IKK} \gamma$ 결핍 마우스에서는 장상피세포의 $\mathrm{NF}-\kappa \mathrm{B}$ 를 통한 신호전달이 억제되어 자발성 장염과 $\mathrm{CD} 4+\mathrm{T}$ 세포 활성화를 유 발하였고, ${ }^{83}$ TLR4, TLR9, Myd88 결핍 마우스에서는 화학물질로 유 도한 장염을 악화시켰다. ${ }^{84}$ 세균 항원에 대한 면역관용은 일차적으로 조절 T세포에 의해 만들어진 IL-10과 TGF- $\beta$ 에 의해 매개되는데, $\mathrm{IL}-10, \mathrm{TGF}-\beta, \mathrm{TGF}-\beta$ 신호경로를 매개하는 $\mathrm{SMAD} 3$, 또는 $\mathrm{CD} 25$ 리간드인 IL-2를 선택적으로 결손시키면 장염이 발생한다. ${ }^{5}$ 염증성 장질환에서 조절 $\mathrm{T}$ 세포 기능의 유전적 또는 기능적 결함에 대한 직접 적인 증거는 없으나, 크론병과 궤양성 대장염에서는 다양한 세균 항 원에 대한 $\mathrm{T}$ 세포와 항체 반응이 나타나고, 경구 면역관용(oral tolerance)이 생기지 않는다. ${ }^{86}$

맺음말

분자생태학적인 분석법이 발전하면서 염증성 장질환에서 장내세균
조성과 대사작용의 변화가 뚜렷함을 알게 되었다. 장내세균은 계속 해서 항원 자극을 함으로써 유전적인 소인이 있는 사람에서 병원성 면 역반응을 유발한다. 점막장벽기능이나 선천성 세균 제거의 유전적인 결함이 초래되면 정상 조절 기전을 초과하는 많은 양의 세균 항원 자 극이 발생하고, 역으로 숙주의 면역조절에 유전적인 결함이 생기면 세 균 항원에 대한 비정상적인 과도한 $\mathrm{T}$ 세포 활성화와 함께 점막면역계 의 면역관용이 소실된다.

숙주 면역계가 장내세균 조성에 중요한 영향을 미치고, 장내세균 역시 숙주 면역계의 발달 및 면역반응에 중요한 역할을 함은 알게 되 었으나, 면역계와 장내세균 간의 상호 조절 기전에 대해선 잘 밝혀져 있지 않다. 또한, 장내세균이 염증성 장질환의 병태생리에 중요한 역 할을 함은 알고 있으나, 아직 장내세균의 조성 및 대사작용의 변화가 염증성 장질환의 원인인지 아니면 질환의 결과로 동반된 현상인지는 모른다.

향후 정상인과 염증성 장질환에서 세균, 바이러스 및 진균의 조성 변화뿐만 아니라 이들의 대사작용과 대사산물의 변화 및 작용에 대 한 많은 연구가 필요하다. 또한 장내 미생물 조성 및 기능변화의 원인 과 결과에 대한 정확한 이해를 위해서는 인체 유전자다형성과 유전 자 발현, 선천면역 및 적응면역계와의 상호작용에 대한 통합적인 고 찰이 필요하며, 이를 통해 미생물-숙주 상호작용을 이해할 수 있을 것으로 기대한다.

\section{REFERENCES}

1. Xavier RJ, Podolsky DK. Unravelling the pathogenesis of inflammatory bowel disease. Nature 2007;448:427-434.

2. Strober W, Fuss I, Mannon P. The fundamental basis of inflammatory bowel disease. J Clin Invest 2007;117:514-521.

3. Mackie RI, Sghir A, Gaskins HR. Developmental microbial ecology of the neonatal gastrointestinal tract. Am J Clin Nutr 1999;69: 1035S-1045S.

4. Dominguez-Bello MG, Costello EK, Contreras M, et al. Delivery mode shapes the acquisition and structure of the initial microbiota across multiple body habitats in newborns. Proc Natl Acad Sci U S A 2010;107:11971-11975.

5. Koenig JE, Spor A, Scalfone N, et al. Succession of microbial consortia in the developing infant gut microbiome. Proc Natl Acad Sci U S A 2011;108(Suppl 1):4578-4585.

6. Martín R, Jiménez E, Heilig $\mathrm{H}$, et al. Isolation of bifidobacteria from breast milk and assessment of the bifidobacterial population by PCR-denaturing gradient gel electrophoresis and quantitative real-time PCR. Appl Environ Microbiol 2009;75:965-969.

7. Palmer C, Bik EM, DiGiulio DB, Relman DA, Brown PO. Development of the human infant intestinal microbiota. PLoS Biol 2007;5:e177.

8. Nicholson JK, Holmes E, Kinross J, et al. Host-gut microbiota metabolic interactions. Science 2012;336:1262-1267.

9. Claesson MJ, Cusack S, O'Sullivan O, et al. Composition, variability, and temporal stability of the intestinal microbiota of the elderly. Proc Natl Acad Sci U S A 2011;108(Suppl 1):4586-4591. 10. Devereux G. The increase in the prevalence of asthma and al- 
lergy: food for thought. Nat Rev Immunol 2006;6:869-874.

11. Kilkkinen A, Virtanen SM, Klaukka T, et al. Use of antimicrobials and risk of type 1 diabetes in a population-based mother-child cohort. Diabetologia 2006;49:66-70.

12. Hviid A, Svanström H, Frisch M. Antibiotic use and inflammatory bowel diseases in childhood. Gut 2011;60:49-54.

13. Qin J, Li R, Raes J, et al. A human gut microbial gene catalogue established by metagenomic sequencing. Nature 2010;464:5965.

14. Frank DN, St Amand AL, Feldman RA, Boedeker EC, Harpaz N, Pace NR. Molecular-phylogenetic characterization of microbial community imbalances in human inflammatory bowel diseases. Proc Natl Acad Sci U S A 2007;104:13780-13785.

15. Gill SR, Pop M, Deboy RT, et al. Metagenomic analysis of the human distal gut microbiome. Science 2006;312:1355-1359.

16. Turnbaugh PJ, Hamady M, Yatsunenko T, et al. A core gut microbiome in obese and lean twins. Nature 2009;457:480-484.

17. Pumbwe L, Skilbeck CA, Nakano V, Avila-Campos MJ, Piazza RM, Wexler HM. Bile salts enhance bacterial co-aggregation, bacterial-intestinal epithelial cell adhesion, biofilm formation and antimicrobial resistance of Bacteroides fragilis. Microb Pathog 2007;43:78-87.

18. Rakoff-Nahoum S, Paglino J, Eslami-Varzaneh F, Edberg S, Medzhitov R. Recognition of commensal microflora by toll-like receptors is required for intestinal homeostasis. Cell 2004;118:229241.

19. Clavel T, Haller D. Bacteria- and host-derived mechanisms to control intestinal epithelial cell homeostasis: implications for chronic inflammation. Inflamm Bowel Dis 2007;13:1153-1164.

20. Strober W, Murray PJ, Kitani A, Watanabe T. Signalling pathways and molecular interactions of NOD1 and NOD2. Nat Rev Immunol 2006;6:9-20.

21. Sartor RB. Microbial influences in inflammatory bowel diseases. Gastroenterology 2008;134:577-594.

22. Johansson ME, Phillipson M, Petersson J, Velcich A, Holm L, Hansson GC. The inner of the two Muc2 mucin-dependent mucus layers in colon is devoid of bacteria. Proc Natl Acad Sci U S A 2008;105:15064-15069.

23. Vaishnava S, Yamamoto M, Severson KM, et al. The antibacterial lectin RegIIIgamma promotes the spatial segregation of microbiota and host in the intestine. Science 2011;334:255-258.

24. Macpherson AJ, Gatto D, Sainsbury E, Harriman GR, Hengartner $\mathrm{H}$, Zinkernagel RM. A primitive T cell-independent mechanism of intestinal mucosal IgA responses to commensal bacteria. Science 2000;288:2222-2226.

25. Macpherson AJ, Uhr T. Induction of protective IgA by intestinal dendritic cells carrying commensal bacteria. Science 2004;303: 1662-1665.

26. Sonnenberg GF, Monticelli LA, Alenghat T, et al. Innate lymphoid cells promote anatomical containment of lymphoidresident commensal bacteria. Science 2012;336:1321-1325.

27. Garrett WS, Lord GM, Punit S, et al. Communicable ulcerative colitis induced by T-bet deficiency in the innate immune system. Cell 2007;131:33-45.
28. Vijay-Kumar M, Aitken JD, Carvalho FA, et al. Metabolic syndrome and altered gut microbiota in mice lacking Toll-like receptor 5. Science 2010;328:228-231.

29. Round JL, Mazmanian SK. The gut microbiota shapes intestinal immune responses during health and disease. Nat Rev Immunol 2009;9:313-323.

30. Bouskra D, Brézillon C, Bérard M, et al. Lymphoid tissue genesis induced by commensals through NOD1 regulates intestinal homeostasis. Nature 2008;456:507-510.

31. Hooper LV, Macpherson AJ. Immune adaptations that maintain homeostasis with the intestinal microbiota. Nat Rev Immunol 2010;10:159-169.

32. Stagg AJ, Hart AL, Knight SC, Kamm MA. Microbial-gut interactions in health and disease. Interactions between dendritic cells and bacteria in the regulation of intestinal immunity. Best Pract Res Clin Gastroenterol 2004;18:255-270.

33. Ng SC, Benjamin JL, McCarthy NE, et al. Relationship between human intestinal dendritic cells, gut microbiota, and disease activity in Crohn's disease. Inflamm Bowel Dis 2011;17:2027-2037.

34. Ivanov II, Atarashi K, Manel N, et al. Induction of intestinal Th17 cells by segmented filamentous bacteria. Cell 2009;139:485-498.

35. Atarashi K, Tanoue T, Shima T, et al. Induction of colonic regulatory T cells by indigenous Clostridium species. Science 2011; 331:337-341.

36. Round JL, Lee SM, Li J, et al. The Toll-like receptor 2 pathway establishes colonization by a commensal of the human microbiota. Science 2011;332:974-977.

37. Sokol H, Seksik P. The intestinal microbiota in inflammatory bowel diseases: time to connect with the host. Curr Opin Gastroenterol 2010;26:327-331.

38. Fritz T, Niederreiter L, Adolph T, Blumberg RS, Kaser A. Crohn's disease: NOD2, autophagy and ER stress converge. Gut 2011;60:1580-1588.

39. Vaishnava S, Behrendt CL, Ismail AS, Eckmann L, Hooper LV. Paneth cells directly sense gut commensals and maintain homeostasis at the intestinal host-microbial interface. Proc Natl Acad Sci U S A 2008;105:20858-20863.

40. Garrett WS, Gordon JI, Glimcher LH. Homeostasis and inflammation in the intestine. Cell 2010;140:859-870.

41. Philpott DJ, Girardin SE. Crohn's disease-associated Nod2 mutants reduce IL10 transcription. Nat Immunol 2009;10:455-457.

42. Lala S, Ogura Y, Osborne C, et al. Crohn's disease and the NOD2 gene: a role for paneth cells. Gastroenterology 2003;125:47-57.

43. Frank DN, Robertson CE, Hamm CM, et al. Disease phenotype and genotype are associated with shifts in intestinal-associated microbiota in inflammatory bowel diseases. Inflamm Bowel Dis 2011;17:179-184.

44. Petnicki-Ocwieja T, Hrncir T, Liu YJ, et al. Nod2 is required for the regulation of commensal microbiota in the intestine. Proc Natl Acad Sci U S A 2009;106:15813-15818.

45. Rehman A, Sina C, Gavrilova O, et al. Nod2 is essential for temporal development of intestinal microbial communities. Gut 2011;60:1354-1362.

46. Cadwell K, Liu JY, Brown SL, et al. A key role for autophagy and 
the autophagy gene Atg16l1 in mouse and human intestinal Paneth cells. Nature 2008;456:259-263.

47. Spehlmann ME, Begun AZ, Burghardt J, Lepage P, Raedler A, Schreiber S. Epidemiology of inflammatory bowel disease in a German twin cohort: results of a nationwide study. Inflamm Bowel Dis 2008;14:968-976.

48. Hansen J, Gulati A, Sartor RB. The role of mucosal immunity and host genetics in defining intestinal commensal bacteria. Curr Opin Gastroenterol 2010;26:564-571.

49. Ott SJ, Musfeldt M, Wenderoth DF, et al. Reduction in diversity of the colonic mucosa associated bacterial microflora in patients with active inflammatory bowel disease. Gut 2004;53:685-693.

50. Barcenilla A, Pryde SE, Martin JC, et al. Phylogenetic relationships of butyrate-producing bacteria from the human gut. Appl Environ Microbiol 2000;66:1654-1661.

51. Hodin R. Maintaining gut homeostasis: the butyrate-NF-kappaB connection. Gastroenterology 2000;118:798-801.

52. Sokol H, Pigneur B, Watterlot L, et al. Faecalibacterium prausnitzii is an anti-inflammatory commensal bacterium identified by gut microbiota analysis of Crohn disease patients. Proc Natl Acad Sci U S A 2008;105:16731-16736.

53. Lepage P, Seksik P, Sutren M, et al. Biodiversity of the mucosaassociated microbiota is stable along the distal digestive tract in healthy individuals and patients with IBD. Inflamm Bowel Dis 2005;11:473-480.

54. Gophna U, Sommerfeld K, Gophna S, Doolittle WF, Veldhuyzen van Zanten SJ. Differences between tissue-associated intestinal microfloras of patients with Crohn's disease and ulcerative colitis. J Clin Microbiol 2006;44:4136-4141.

55. Vasquez N, Mangin I, Lepage P, et al. Patchy distribution of mucosal lesions in ileal Crohn's disease is not linked to differences in the dominant mucosa-associated bacteria: a study using fluorescence in situ hybridization and temporal temperature gradient gel electrophoresis. Inflamm Bowel Dis 2007;13:684-692.

56. Walker AW, Sanderson JD, Churcher C, et al. High-throughput clone library analysis of the mucosa-associated microbiota reveals dysbiosis and differences between inflamed and noninflamed regions of the intestine in inflammatory bowel disease. BMC Microbiol 2011;11:7.

57. Eckburg PB, Bik EM, Bernstein CN, et al. Diversity of the human intestinal microbial flora. Science 2005;308:1635-1638.

58. Zoetendal EG, von Wright A, Vilpponen-Salmela T, Ben-Amor $\mathrm{K}$, Akkermans AD, de Vos WM. Mucosa-associated bacteria in the human gastrointestinal tract are uniformly distributed along the colon and differ from the community recovered from feces. Appl Environ Microbiol 2002;68:3401-3407.

59. Hehemann JH, Correc G, Barbeyron T, Helbert W, Czjzek M, Michel G. Transfer of carbohydrate-active enzymes from marine bacteria to Japanese gut microbiota. Nature 2010;464:908-912.

60. De Filippo C, Cavalieri D, Di Paola M, et al. Impact of diet in shaping gut microbiota revealed by a comparative study in children from Europe and rural Africa. Proc Natl Acad Sci U S A 2010;107:14691-14696.

61. Rehman A, Lepage P, Nolte A, Hellmig S, Schreiber S, Ott SJ.
Transcriptional activity of the dominant gut mucosal microbiota in chronic inflammatory bowel disease patients. J Med Microbiol 2010;59:1114-1122.

62. Verberkmoes NC, Russell AL, Shah M, et al. Shotgun metaproteomics of the human distal gut microbiota. ISME J 2009;3:179189.

63. Li M, Wang B, Zhang M, et al. Symbiotic gut microbes modulate human metabolic phenotypes. Proc Natl Acad Sci U S A 2008;105:2117-2122.

64. Kotlowski R, Bernstein CN, Sepehri S, Krause DO. High prevalence of Escherichia coli belonging to the $\mathrm{B} 2+\mathrm{D}$ phylogenetic group in inflammatory bowel disease. Gut 2007;56:669-675.

65. Darfeuille-Michaud A, Boudeau J, Bulois P, et al. High prevalence of adherent-invasive Escherichia coli associated with ileal mucosa in Crohn's disease. Gastroenterology 2004;127:412-421.

66. Pineton de Chambrun G, Colombel JF, Poulain D, DarfeuilleMichaud A. Pathogenic agents in inflammatory bowel diseases. Curr Opin Gastroenterol 2008;24:440-447.

67. Barnich N, Carvalho FA, Glasser AL, et al. CEACAM6 acts as a receptor for adherent-invasive E. coli, supporting ileal mucosa colonization in Crohn disease. J Clin Invest 2007;117:1566-1574.

68. Naser SA, Ghobrial G, Romero C, Valentine JF. Culture of Mycobacterium avium subspecies paratuberculosis from the blood of patients with Crohn's disease. Lancet 2004;364:1039-1044.

69. Feller M, Huwiler K, Stephan R, et al. Mycobacterium avium subspecies paratuberculosis and Crohn's disease: a systematic review and meta-analysis. Lancet Infect Dis 2007;7:607-613.

70. Abubakar I, Myhill D, Aliyu SH, Hunter PR. Detection of Mycobacterium avium subspecies paratuberculosis from patients with Crohn's disease using nucleic acid-based techniques: a systematic review and meta-analysis. Inflamm Bowel Dis 2008;14: 401-410.

71. Kirkwood CD, Wagner J, Boniface K, et al. Mycobacterium avium subspecies paratuberculosis in children with early-onset Crohn's disease. Inflamm Bowel Dis 2009;15:1643-1655.

72. Cadwell K, Patel KK, Maloney NS, et al. Virus-plus-susceptibility gene interaction determines Crohn's disease gene Atg16L1 phenotypes in intestine. Cell 2010;141:1135-1145.

73. Rehaume LM, Jouault T, Chamaillard M. Lessons from the inflammasome: a molecular sentry linking Candida and Crohn's disease. Trends Immunol 2010;31:171-175.

74. Kim H, Rhee SH, Pothoulakis C, Lamont JT. Inflammation and apoptosis in Clostridium difficile enteritis is mediated by PGE2 up-regulation of Fas ligand. Gastroenterology 2007;133:875-886.

75. Rabizadeh S, Rhee KJ, Wu S, et al. Enterotoxigenic bacteroides fragilis: a potential instigator of colitis. Inflamm Bowel Dis 2007;13:1475-1483.

76. Marchesi JR, Holmes E, Khan F, et al. Rapid and noninvasive metabonomic characterization of inflammatory bowel disease. J Proteome Res 2007;6:546-551.

77. Loubinoux J, Bronowicki JP, Pereira IA, Mougenel JL, Faou AE. Sulfate-reducing bacteria in human feces and their association with inflammatory bowel diseases. FEMS Microbiol Ecol 2002;40:107-112. 
78. Hilsden RJ, Meddings JB, Sutherland LR. Intestinal permeability changes in response to acetylsalicylic acid in relatives of patients with Crohn's disease. Gastroenterology 1996;110:1395-1403.

79. Russell RK, Drummond HE, Nimmo ER, et al. Analysis of the influence of OCTN1/2 variants within the IBD5 locus on disease susceptibility and growth indices in early onset inflammatory bowel disease. Gut 2006;55:1114-1123.

80. Ho GT, Nimmo ER, Tenesa A, et al. Allelic variations of the multidrug resistance gene determine susceptibility and disease behavior in ulcerative colitis. Gastroenterology 2005;128:288-296.

81. Wehkamp J, Salzman NH, Porter E, et al. Reduced Paneth cell alpha-defensins in ileal Crohn's disease. Proc Natl Acad Sci U S A 2005;102:18129-18134.

82. Hampe J, Franke A, Rosenstiel P, et al. A genome-wide association scan of nonsynonymous SNPs identifies a susceptibility variant for Crohn disease in ATG16L1. Nat Genet 2007;39:207211.

83. Nenci A, Becker C, Wullaert A, et al. Epithelial NEMO links innate immunity to chronic intestinal inflammation. Nature 2007; 446:557-561.

84. Lee J, Mo JH, Katakura K, et al. Maintenance of colonic homeostasis by distinctive apical TLR9 signalling in intestinal epithelial cells. Nat Cell Biol 2006;8:1327-1336.

85. Schultz M, Tonkonogy SL, Sellon RK, et al. IL-2-deficient mice raised under germfree conditions develop delayed mild focal intestinal inflammation. Am J Physiol 1999;276:G1461-G1472.

86. Kraus TA, Toy L, Chan L, Childs J, Mayer L. Failure to induce oral tolerance to a soluble protein in patients with inflammatory bowel disease. Gastroenterology 2004;126:1771-1778. 